\title{
Is neutrophil to lymphocyte ratio a predictive factor for recurrence of urethral stricture?
}

\author{
(iD) Ahmet Urkmez' \\ Damazan Topaktas ${ }^{1}$ \\ (iD) Emrah Ozsoy ${ }^{1}$ \\ (iD) Emre Tokuc ${ }^{1}$ \\ (iD) Musab Ali Kutluhan² \\ (iD)llker Artuk ${ }^{1}$ \\ (iD) Ridvan Kayar ${ }^{1}$ \\ (iD) Metin Ishak Ozturk ${ }^{1}$
}

1. Haydarpasa Numune Research \& Training Hospital, Dept. of Urology, Istanbul, Turkey 2. Fatih Sultan Mehmet Research \& Training Hospital, Dept. of Urology, Istanbul, Turkey

http://dx.doi.org/10.1590/1806-9282.65.12.1448

\section{SUMMARY}

INTRODUCTION: Due to spongiofibrosis and inflammatory processes underlying the pathogenesis of urethral stricture, it is possible that the neutrophil-lymphocyte ratio (NLR) may give essential information about the course of the disease and recurrence possibilities. Our study aims to evaluate the correlation between NLR and recurrence rates.

METHODS: A total of 512 patients who underwent direct visual internal urethrotomy (DVIU) due to urethral stricture in our clinic between February 2010 and January 2018 were evaluated retrospectively.

RESULTS: The median follow up for non-recurrent and recurrent groups after DVIU was 30 and 36 months, respectively. During the follow-up, 280 (54.7\%) of the patients had recurrences, and 232 (45,3\%) had no recurrences. The mean time for recurrence after DVIU was 6,5 $\pm 1,4$ months, with a range of 1-36 months. The mean NLR in the non-recurrence group was 2,02 $\pm 0,87$, with a median of 1.9, and 3,66 2,30 , with a median of 3 in the recurrence group. A highly significant statistical difference was observed between two groups in terms of neutrophil count and NLR ( $p$ : 0.000 - both). The area under curve value for NLR was 0.767, with a standard error of 0.021 (95\% Cl 0.727-0.808). The cut-off value of NLR was determined as 2.25, with a 70\% sensitivity and 67,7\% specificity.

CONCLUSION: By using NLR, the inflammatory features of the urethral tissue can be predicted, and possible recurrences after surgery can be estimated. Consequently, open urethroplasty techniques can be used in cases with a significant NLR value instead of the recurrent endoscopic procedure.

KEYWORDS: Inflammation. Urethra/surgery. Recurrence. Urethral stricture. Urologic Surgical Procedures, Male.

\section{INTRODUCTION}

Urethral stricture is a relatively common and debilitant disease, with an incidence of $0.6 \%$, which occurs due to several different etiologic reasons in different age groups. ${ }^{1}$ Etiology mostly consists of iatrogenic reasons (catheterization/endoscopic procedures), as well as trauma, infections, prostatecto- my, and other post-prostate cancer treatments, lichen sclerosis, and idiopathic reasons. ${ }^{2}$ Its incidence is higher in older and African-American men. ${ }^{1}$ The main pathophysiological factor for urethral stricture is spongiofibrosis, causing scar tissues in the corpus spongiosum and narrowing the urethral lumen as a 
result. The process leading to this fibrosis is primarily subepithelial inflammation and hemorrhage, and later stages are characterized as sclerosis and fibrosis. ${ }^{3}$ The latest molecular studies show that there is a disproportion between collagen type 1 over collagen type 3. It has also been found that this spongiofibrotic process may be induced by inflammatory mediators such as neuronal nitric oxide synthase 1 and transforming growth factor beta (TGF- $\beta$ ) in connective tissue. ${ }^{4,5}$

White blood cells differentiate as neutrophils and lymphocytes as a response to inflammation. Elevated neutrophil to lymphocyte ratio (NLR) is associated with chronic inflammation and found to be a marker to estimate the progression and prognosis of many diseases and types of cancer. ${ }^{6-8}$ Since the endoscopic procedures are a factor of urethral stricture, which disfigures the smoothness and continuity of the urethral mucosa and the microstructure of the corpus spongiosum, recurrence is frequent. Recurrence rates vary from $23-92 \%$ in endoscopic procedures and $5-14 \%$ in open reconstructive surgery techniques. ${ }^{9,10}$ Direct visual internal urethrotomy (DVIU) is the most common type of surgery in cases of strictures mostly in the bulbar urethra and short stricture length. ${ }^{9}$ Its lower complexity and effort-time efficiency make this technique an eligible choice. ${ }^{11}$

Due to the spongiofibrosis and inflammatory processes underlying the pathogenesis of urethral stricture, NLR may give essential information about the course of the disease and recurrence possibilities. Our study aims to evaluate the correlation between NLR and recurrence rates.

\section{METHODS}

After obtaining approval by the institutional review board, 512 patients who underwent DVIU due to urethral stricture in our clinic between February 2010 and January 2018 were evaluated retrospectively. Patients' age at the time of the surgery, location, and length of stenosis in the operation reports, follow-up period, and previous DVIU history of the patients who were referred from outer centers were recorded. In addition, neutrophil, lymphocyte, neutrophil/lymphocyte ratio, hematocrit, and albumin levels were recorded from complete blood count and biochemistry analyses done for preoperative anesthesia assessment. After a descriptive analysis of the patients, comparative statistics were performed in 2 groups, one with no recurrence after the DVIU procedure, and the other with one or more recurrence. Patients with malignancies, uncontrolled diabetes mellitus, hematologic, liver, or kidney dysfunction, who received blood transfusions, and with a previous open urethral surgery were excluded. Urine culture tests were performed on each patient preoperatively, and the surgeries of patients with active infections were postponed until the treatment was completed. Blood counts of all patients were made on a stationary device in the hospital's central laboratory, which is regularly checked.

In our clinic, DVIU is applied as a standard to patients who are surgery-naïve and have short segment bulbar urethral stricture $(<1.5 \mathrm{~cm}$, mostly $<1 \mathrm{~cm})$. After admitting an appropriate prophylactic single dose of antibiotics, all operations were performed in a lithotomy position. The standard procedure of DVIU in our clinic is performed with a single incision using a cold-knife at 12 o'clock position. A 16-18F silicone catheter is applied after the surgery and is removed routinely on the $2^{\text {nd }}$ day postoperatively. Open urethroplasty is the choice of treatment in long segment strictures and recurrence after DVIU. Our clinic is a reference center for open urethroplasty, and patients with recurrent strictures after DVIU are referred from many other clinics. Most of the patients included in our study with one or more recurrence after DVIU consists of these kinds of patients. In our clinic, self-catheterization or bougie dilatation procedure is not applied to avoid or delay recurrences. Patients underwent clinical evaluation and uroflowmetry every three months for one year after DVIU and, later, every six months for two years. The time for recurrence was defined as the time from DVIU to the first clinical sign of recurrence (symptoms and uroflowmetric evaluation) or the date of subsequent repeat DVIU or urethroplasty surgery.

\section{STATISTICAL ANALYSIS}

Statistical analysis was performed using the IBM SPSS Statistics 25 software. The study data was evaluated by the Shapiro-Wilks test in terms of distribution, and the parameters were assessed as not normally distributed. Descriptive statistical methods (mean, standard deviation, frequency), as well as the Mann-Whitney U test, were used for the comparison of the two groups when evaluating the study data. $\mathrm{P}$ $<0.05$ was assessed as significance. 


\section{RESULTS}

A total of 512 patients were included in the study. The mean age of the patients with and without recurrence after DVIU was 52,9 $\pm 11,6$ and $50,6 \pm 10,8$, respectively. There was no significant difference between the mean ages of both groups. The mean follow-up for the non-recurrent group after DVIU was $31,7 \pm 6,4$ months, with a range of $6-63$ months, and the median follow up was 30 months. The mean follow-up for the recurrent group after DVIU was $35,2 \pm 9,1$ months with a range of 6-72 months, and the median follow up was 36 months. During the follow-up, after the first DVIU procedure, 280 (54.7\%) of the patients had recurrences, and $232(45,3 \%)$ had no recurrences (Table 1). The mean time to recurrence after DVIU was $6,5 \pm 1,4$ months with a range of 1-36 months, and the median time to recurrence was seven months. The total number of recurrences seen in patients varies from 1 to 7 , with an average of $1.83 \pm 1.34$ and a median of 1 . Neutrophil, lymphocyte, and hematocrit levels were present in all patients since they were routinely performed during anesthesia assessment, while preoperative albumin values were present in 249 of 512 patients. A total of 144 of the 249 patients were in the non-recurrence group, and 105 were in the recurrence group.

TABLE 1. EVALUATION OF BASIC PARAMETERS, HEMATOLOGIC PARAMETERS AND NLR ACCORDING TO THE PRESENCE OF RECURRENCE

\begin{tabular}{|l|l|l|}
\hline \multirow{2}{*}{} & \multicolumn{2}{|l|}{ Recurrence } \\
\cline { 2 - 3 } & No (n:232) & Yes (n:280) \\
\cline { 2 - 3 } & Mean \pm SD (Range) & Mean $\pm S D$ (Range)p \\
\hline Patient age (year) & $52.9 \pm 11.6$ (23-78) & $50.6 \pm 10.8(21-75)$ \\
\hline Follow up (months) & $31.7 \pm 6.4(6-63)$ & $35.2 \pm 9.1(6-72)$ \\
\hline $\begin{array}{l}\text { Time to recurrence } \\
\text { (months) }\end{array}$ & & $6.5 \pm 1.4(1-36)$ \\
\hline
\end{tabular}

\begin{tabular}{|l|l|l|l|}
\hline $\begin{array}{l}\text { Neutrophil } \\
\text { (mean) }\end{array}$ & 4 & & $\begin{array}{l}.43 \pm 1.61(4.41) \\
5.79 \pm 2.34(5.4) \\
0.000^{*}\end{array}$ \\
\hline $\begin{array}{l}\text { Lymphocyte } \\
\text { (mean) }\end{array}$ & 2 & & $\begin{array}{l}.38 \pm 1.08(2.24) \\
1.87 \pm 0.80(1.79) \\
0.000^{*}\end{array}$ \\
\hline NLR (mean) & 2 & & $\begin{array}{l}.02 \pm 0.87(1.9) \\
3.66 \pm 2.30(3.04) \\
0.000^{*}\end{array}$ \\
\hline $\begin{array}{l}\text { Hematocrit } \\
\text { (mean) }\end{array}$ & 40 & & $\begin{array}{l}.31 \pm 5.27(41.4) \\
40.24 \pm 5.69(40.9) \\
0.950\end{array}$ \\
\hline Albumin (mean) & $4.2 \pm 3.32(4)$ & $\begin{array}{l}3 \\
.91 \pm 0.41\end{array}$ & 0.531 \\
& & $(3.9)$ & \\
\hline
\end{tabular}

Mann Whitney U Test. NLR: neutrophil to lymphocyte ratio $\quad$ * $p<0.005$
In the non-recurrence group, mean neutrophil levels were $4,43 \pm 1,61$, with a median of 4.4 . The mean neutrophil levels in the recurrence group were $5,79 \pm 2,34$, with a median of 5.4 . The mean lymphocyte levels in the non-recurrence and recurrence groups were $2,38 \pm 1,08$, with a median of 2.2 and $1,87 \pm 0,8$ with a median of 1.8 , respectively. The mean NLR in the non-recurrence group was $2,02 \pm 0,87$ with a median of 1.9 , and $3,66 \pm 2,30$ with a median of 3 in the recurrence group. The mean hematocrit levels were 40,31 $\pm 5,27$ (median 41.4) and 40,24 $\pm 5,69$ (median 40.9) respectively. Finally, mean albumin levels were $4,2 \pm 3,32$ (median 4 ) in the non-recurrence group, and 3,91 $\pm 0,41$ (median $3.9)$ in the recurrence group. A highly significant statistical difference was observed between two groups in terms of neutrophil count and neutrophil-lymphocyte ratio. (p: 0.000 - both). The area under curve (AUC) value for NLR was 0.767 , with a standard error of 0.021 (95\% CI 0.727-0.808)(Figure 1). The cut-off value of NLR in the detection of recurrence after internal urethrotomy was determined as 2.25 , with a $70 \%$ sensitivity, $67,7 \%$ specificity. There was no statistically significant difference between the groups in terms of lymphocyte, hematocrit, and albumin levels ( $p>0.05)$ (Table 1).

\section{DISCUSSION}

Managing urethral strictures is a challenge for surgeons and can be a burden to both the patient and the surgeon. It is still uncertain which patients need which kind of procedure. Endoscopic interventions are simple and easy to apply but have high recurrence rates. Contrarily, open techniques are promising with better long-term results but require high expertise, precise technique, and special instrumentation. ${ }^{12}$ Predicting the recurrence rates before deciding on the technique for each patient can help surgeons offer the most beneficial procedure. While many studies on NLR have been performed in many different fields in the literature, as far as we know, our study is the first involving urethral strictures.

In recent years, it has been shown that NLR may be a marker of chronic systemic inflammation and is associated with prognosis in many cardiovascular diseases, malignancies, and chronic inflammatory diseases. These markers were previously assessed in various uro-oncologic cases and have been shown to have an effective role in both predicting postoperative 
FIGURE 1. ROC CURVE OF NEUTROPHIL-LYMPHOCYTE RATIO IN THE PREDICTION OF RECURRENCE AFTER INTERNAL URETHROTOMY

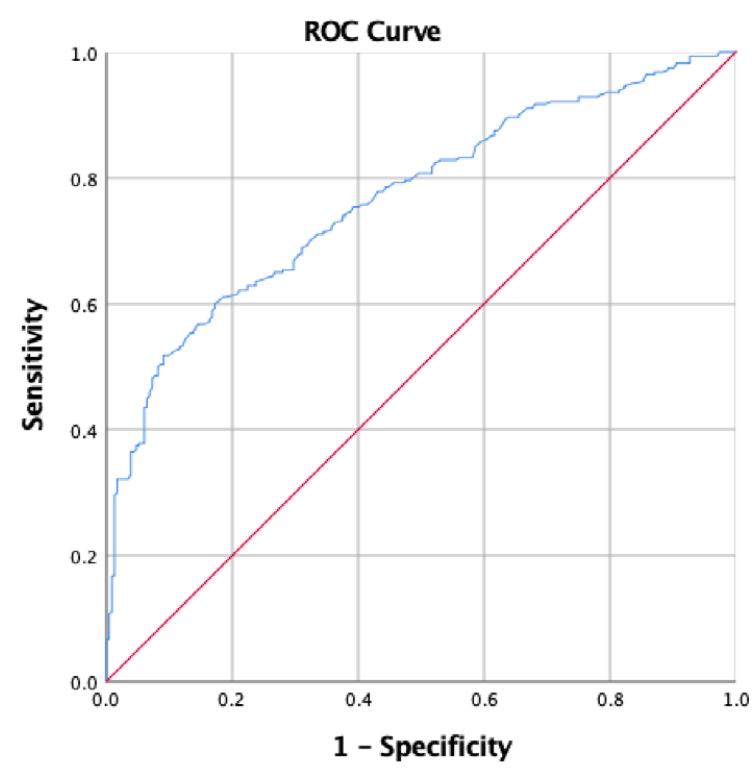

surgical margin status and progression-free survival. ${ }^{13,14}$ In a study that regarded a NLR of 2.7 as a limit, it was shown that a combination of tumor stage and NLR could be used to assess the risk of recurrence in patients with non-metastatic renal cell carcinoma. ${ }^{15}$ Another study showed that NLR in non-clear-cell kidney tumors was an independent prognostic factor for disease-free survival after curative surgery. As such, NLR has been reported to be a significant marker for patient counseling and clinical trial design. ${ }^{16}$

Inflammation, especially chronic inflammation in organs with lumens, can lead to stenosis and obstruction by causing fibrosis. Based on this hypothesis, inflammation markers can be used as a predictive factor in the development of restenosis and obstruction. In a study conducted by Qian et al.17 on 261 coronary artery patients, inflammation markers were evaluated in groups with and without restenosis, and it concluded that these markers could be used as an independent predictive factor for restenosis development. In 2019, Velioglu and Yuksel $^{18}$ investigated the relationship between inflammation and peripheral arterial disease. They concluded that the higher the NLR, which is used as an indicator of inflammation, the higher the severity of the peripheral arterial disease. In this study, the severity of inflammation in tissues with a lumen is used to predict the pathology inside the lumen. This has been evaluated in internal urethrotomy patients. By using NLR, especially in frequent and multiple recurrent patients, the inflammatory features of the tissue could be predicted and possible recurrences after surgery estimated.

Recurrences after DVIU can be due to infection and inflammation after the operation. When urethral strictures are considered, fibroblasts are probably responsible for the development of the urethral stricture; however, the reason for the urethral stricture is related to the urinary extravasation into the subepithelial space causing increased inflammation and subsequent scar formation. With this knowledge, many authors have used colchicine, mitomycin-C, triamcinolone, corticosteroids, and anti-inflammatory drugs locally or systemically to reduce urethral stricture after urethral procedures. ${ }^{19}$ In this context, the urethral stricture is a result of inflammatory changes in the epithelium of the urethra and can be treated by interfering with the inflammatory process. We used anti-inflammatory drugs (COX-2 inhibitors) for three days after the operation to reduce inflammation in our cases.

In patients with urethral stricture, anti-fibrosis agents were used to prevent a recurrence. In a very recent study conducted in 2018, patients who received $10 \mathrm{mg}$ tamoxifen daily for six months after internal urethrotomy were compared with the control group, and tamoxifen was shown to significantly reduce re-fibrosis and stricture development. Again in 2016, in a study with 83 patients, Yıldırım et al. ${ }^{20}$ showed that recurrence is significantly lower in patients who received a local urethral steroid injection compared with a control. Sinanoglu et al. ${ }^{21}$ conducted a similar study with 84 patients and used colchicine as an anti-inflammatory agent, and the recurrence in this group was significantly lower.

It is known that white blood cells differ in systemic inflammation, such as neutrophilia and lymphopenia. ${ }^{6}$ This inflammatory response and tissue necrosis leads to fibrosis and poor recipient vascularity, which likely has a key role in deficient wound healing, which, in turn, threatens urethroplasty success. ${ }^{22}$ In a related study of 208 patients with a history of urethral stricture after transurethral resection of the prostate, it was shown that the NLR was relatively higher in relapsed patients but not significant. ${ }^{19}$ Chronic inflammation in the urethral tissue, as well as inflammation of the prostate tissue, may be effective in the development of urethral stricture, especially after endoscopic procedures. Grechenkov et al. ${ }^{23}$ found that patients who have chronic prostatic 
inflammation after TUR-P have a significantly higher risk of developing urethral stricture than patients without prostatic inflammation.

Acute or chronic inflammation-fibrosis-sclerosis may be effective in the recurrence of urethral strictures. Some histological studies support this theory. Ekerhult et al..$^{24}$ examined the stenosis segment histopathologically in 45 patients with open urethroplasty and found a significantly increased risk of developing stenosis after urethroplasty in patients with sclerosis, compared to those without it. Inflammation and established sclerosis are prominent, especially in patients with recurrent urethral strictures. Recurrent endoscopic urethrotomy procedures in sclerotic tissue may cause recurrence and not provide curative results. In these cases, NLR can be used as a predictive value. Open urethroplasty techniques can be used in cases with a significant NLR value by using grafts or flaps instead of recurrent endoscopic procedures. Also, in our study, there were statistically significant differences between neutrophils and NLR in patients with and without stricture recurrence after DVIU.

Our study is not free of limitations because of its retrospective design. There are deficiencies related to the previous follow-up of patients referred to our clinic from outer centers, especially after repeated urethrotomy procedures from outer centers. The main limitations of our study are its single-center design, the relatively limited number of patients, its retrospective nature, and the exclusion of older patients due to additional comorbidities.

\section{CONCLUSION}

By using NLR, the inflammatory features of the urethral tissue can be predicted, and possible recurrences after surgery can be estimated. In this manner, open urethroplasty techniques can be used in cases with a significant NLR value instead of the recurrent endoscopic procedure.

Ethical Approval: All procedures performed in studies involving human participants were per the ethical standards of the institutional and/or national research committee and with the 1964 Helsinki declaration and its later amendments or comparable ethical standards.

\section{Conflict of Interest}

The authors declare they have no conflicts of interest.

\section{Funding}

This research did not receive any specific grant from funding agencies in the public, commercial, or non-profit sectors.

\section{Authors' contributions}

AU, RT, and MAK conceived the study, participated in its design and coordination, drafted the manuscript, and revised it critically for important intellectual content. EO, ET, RK, and IA participated in the design of the study and made substantial contributions to the acquisition and interpretation of data. MIO participated in its design and drafted the manuscript. All authors read and approved the final manuscript.

\section{RESUMO}

INTRODUÇãO: Devido à espongiofibrose e processos inflamatórios subjacentes à patogênese da estenose uretral, pode-se pensar que a relação de linfócitos neutrofilicos (NLR) pode fornecer informações essenciais sobre o curso da doença e as possibilidades de recorrência. O objetivo do nosso estudo é avaliar a correlação entre NLR e taxas de recorrência.

MÉTODOS: Quinhentos e doze pacientes submetidos à uretrotomia interna visual direta (DVIU) devido à estenose uretral em nossa clínica entre as datas de fevereiro de 2010 e janeiro de 2018 foram avaliados retrospectivamente.

RESULTADOS: A mediana de acompanhamento para os grupos não recorrentes e recorrentes após a DVIU foi de 30 e 36 meses, respectivamente. Durante o seguimento, 280 (54,7\%) dos pacientes tiveram recidivas e 232 (45,3\%) não tiveram recidivas. 0 tempo médio de

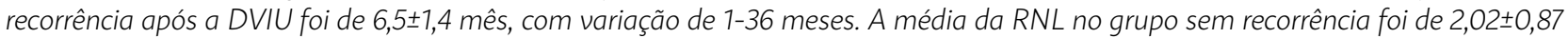
com mediana de 1,9 e 3,66 2,30 com mediana de 3 no grupo com recidiva. Uma diferença estatística altamente significativa foi observada entre dois grupos em termos de contagem de neutrófilos e NLR (p: 0,000 - ambos). A área sob o valor da curva para NLR foi de 0,767 com um erro padrão de 0,021 (IC 95\% 0,727-0,808). Valor de corte de NLR determinado como 2,25 com uma sensibilidade de $70 \%$, especificidade de $67,7 \%$.

CONCLUSÃO: Ao utilizar a RNL, as características inflamatórias do tecido uretral podem ser previstas e possíveis recidivas após a cirurgia podem ser estimadas. Dessa forma, técnicas de uretroplastia aberta podem ser usadas em casos com valor significativo de NLR em vez de procedimento endoscópico recorrente.

PALAVRAS-CHAVE: Inflamação. Uretra/cirurgia. Recidiva. Estreitamento uretral. Procedimentos cirúrgicos urológicos masculinos. 


\section{REFERENCES}

1. Alwaal A, Blaschko SD, McAninch JW, Breyer BN. Epidemiology of urethral strictures. Transl Androl Urol. 2014;3(2):209-13.

2. Lumen N, Hoebeke P, Willemsen P, De Troyer B, Pieters R, Oosterlinck W. Etiology of urethral stricture disease in the $21^{\text {st }}$ century. | Urol. 2009;182(3):983-7.

3. Hampson LA, McAninch JW, Breyer BN. Male urethral strictures and their management. Nat Rev Urol. 2014;11(1):43-50.

4. Baskin LS, Constantinescu SC, Howard PS, McAninch JW, Ewalt DH, Duckett JW, et al. Biochemical characterization and quantification of the collagenous components of urethral stricture tissue. J Urol. 1993;150(2 Pt 2):642-7.

5. Zhang P, Shi M, Wei Q, Wang K, Li X, Li H, et al. Increased expression of connective tissue grow factor in patients with urethral stricture. Tohoku Exp Med. 2008;215(3):199-206.

6. Aktas G, Sit M, Dikbas O, Erkol H, Altinordu R, Erkus E, et al. Elevated neutrophil-to-lymphocyte ratio in the diagnosis of Hashimoto's thyroiditis. Rev Assoc Med Bras. 2017;63(12):1065-8.

7. Costa CH, Rufino R, Lapa e Silva JR. Inflammatory cells and their mediators in COPD pathogenesis. Rev Assoc Med Bras. 2009;55(3):347-54.

8. Yuksel OH, Verit A, Sahin A, Urkmez A, Uruc F. White blood cell counts and neutrophil to lymphocyte ratio in the diagnosis of testicular cancer: a simple secondary serum tumor marker. Int Braz J Urol. 2016;42(1):53-9.

9. Kluth LA, Ernst L, Vetterlein MW, Meyer CP, Reiss CP, Fisch M, et al. Direct vision internal urethrotomy for short anterior urethral strictures and beyond: success rates, predictors of treatment failure, and recurrence management. Urology. 2017;106:210-5.

10. Sukumar S, Elliott SP, Myers |B, Voelzke BB, Smith TG $3^{\text {rd }}$, Carolan AMC, et al. Multi-institutional outcomes of endoscopic management of stricture recurrence after bulbar urethroplasty. J Urol. 2018;200(4):837-42.

11. Tolkach $Y$, Herrmann T, Merseburger A, Burchardt M, Wolters M, Huusmann $\mathrm{S}$, et al. Development of a clinical algorithm for treating urethral strictures based on a large retrospective single-center cohort. Version2. F1000Res. 2016:5:2378

12. Ferguson GG, Bullock TL, Anderson RE, Blalock RE, Brandes SB. Minimally invasive methods for bulbar urethral strictures: a survey of members of the American Urological Association. Urology. 2011;78(3):701-6.
13. Krane LS, Richards KA, Kader AK, Davis R, Balaji KC, Hemal AK. Preoperative neutrophil/lymphocyte ratio predicts overall survival and extravesical disease in patients undergoing radical cystectomy. J Endourol. 2013;27(8):1046-50.

14. Grimes N, Hannan C, Tyson M, Thwaini A. The role of neutrophil-lymphocyte ratio as a prognostic indicator in patients undergoing nephrectomy for renal cell carcinoma. Can Urol Assoc |. 2018;12(7):E345-8.

15. Ohno Y, Nakashima J, Ohori M, Hatano T, Tachibana M. Pretreatment neutrophil-to-lymphocyte ratio as an independent predictor of recurrence in patients with nonmetastatic renal cell carcinoma. J Urol. 2010;184(3):873-8.

16. Martino M, Pantuck AJ, Hofbauer S, Waldert M, Shariat SF, Belldegrun AS, et al. Prognostic impact of preoperative neutrophil-to-lymphocyte ratio in localized nonclear cell renal cell carcinoma. J Urol. 2013;190:1999-2004.

17. Qian H, Luo Z, Xiao C, Chen J, Li D, Xu H, et al. Red cell distribution width in coronary heart disease: prediction of restenosis and its relationship with inflammatory markers and lipids. Postgrad Med J. 2018;94(1115):489-94.

18. Velioglu Y, Yuksel A. Complete blood count parameters in peripheral arterial disease. Aging Male. 2019;22(3):187-91.

19. Gül M, Altıntaş E, Kaynar M, Buğday MS, Göktaş S. The predictive value of platelet to lymphocyte and neutrophil to lymphocyte ratio in determining urethral stricture after transurethral resection of prostate. Turk J Urol. 2017;43(3):325-9.

20. Yıldırım ME, Kaynar M, Ozyuvali E, Badem H, Cakmak M, Kosem B, et al. The effectiveness of local steroid injection after internal urethrotomy to avoid recurrence. Arch Ital Urol Androl. 2016;87(4):295-8.

21. Sinanoglu $O$, Kurtulus FO, Akgün FS. Long-term effect of colchicine treatment in preventing urethral stricture recurrence after internal urethrotomy. Urol J. 2018;15(4):204-8.

22. Chapman D, Kinnaird A, Rourke K. Independent predictors of stricture recurrence following urethroplasty for isolated bulbar urethral strictures. J Urol. 2017;198(5):1107-12.

23. Grechenkov A, Sukhanov R, Bezrukov E, Butnaru D, Barbagli G, Vasyutin I, et al. Risk factors for urethral stricture and/or bladder neck contracture after monopolar transurethral resection of the prostate for benign prostatic hyperplasia. Urologia. 2018;85(4):150-7.

24. Ekerhult TO, Lindqvist K, Grenabo L, Kåbjörn Gustafsson C, Peeker R. Sclerosis as a predictive factor for failure after bulbar urethroplasty: a prospective single-centre study. Scand J Urol. 2018;52(4):302-8. 